\title{
MaHolnap ${ }^{1}$
}

\section{Társadalmi felzárkózási szemle}

\author{
MASZLAG FANNI ${ }^{2}$
}

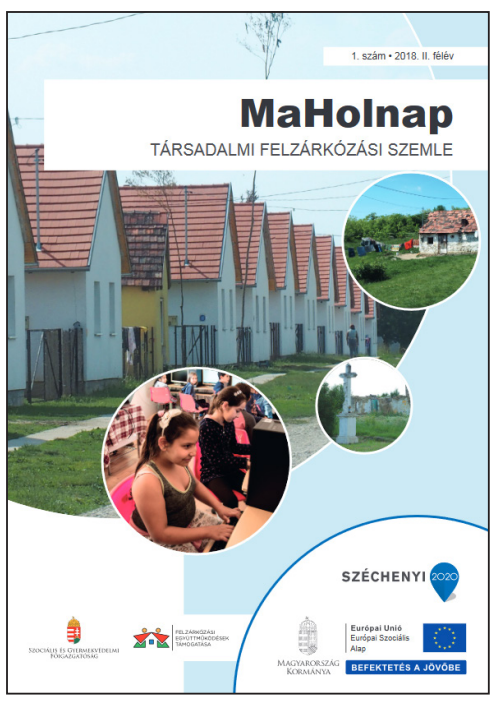

A szemle a társadalmi felzárkózással összefüggő jelenségek, beavatkozások, folyamatok bemutatására létrehozott folyóirat, amelynek a jelentőségét az adja, hogy cikkeiben a felzárkózással összefüggő korábbi hasonló írásokban kevésbé részletezett összefüggéseket, a kistelepülési szegregált élethelyzetekre irányuló információkat és tudást közvetít. A MaHolnap Társadalmi felzárkózási szemle célja egyrészt a települési programok szakmai módszertani támogatása, másrészt a társadalmi felzárkózást elősegíteni kívánó szakemberek tevékenységeinek ismertetése. A szemle kisebb tudományos közleményeken keresztül mutatja be az olvasónak a felzárkózási folyamat összetettségét, a felzárkózás és a települési közösségek viszonyát, illetve a témával foglalkozó szakemberek gyakorlati munkáját.

A folyóirat szerkesztői nem csak leírják a társadalomban megjelenő egyenlőtlenségek különböző formáit, színtereit, a hozzájuk kapcsolódó korábbi kutatások eredményeit, hanem a felzárkózás minél szélesebb területét érintő működési mechanizmusokat is elemzik. A folyóirat szerkezetét tekintve több részből áll. Az első szám első részében Langerné Victor Katalin, az EMMI társadalmi felzárkózásért felelős helyettes államtitkára beszél a társadalmi felzárkózással kapcsolatos programok szegénységcsökkentő szerepéről, illetve a folyóirat jelentőségéről ebben a munkában. Ezt követően Kovács Gábor és Szarvák Tibor összefoglalóan írnak arról, hogy a vidékfejlesztésnek milyen szerepe van a felzárkózási programokban. Tanulmányuk-

\footnotetext{
${ }^{1}$ MaHolnap Társadalmi felzárkózási szemle, 1. szám • 2018. II. félév, ISSN 2631-0791.

${ }^{2}$ Debreceni Egyetem, Humán Tudományok Doktori Iskola Szociológia és társadalompolitika doktori program, doktorandusz.
} 


\section{RECENZIÓ}

ban ismertetik a szociális munka azon módszereit, amelyek elősegíthetik a közösségek és kultúrák közötti kapcsolatok építését és javítását. Ilyen „híd” például a tanoda program, mely a családi szocializációs hiányosságokat kívánja pótolni, valamint a Magyar Máltai Szeretetszolgálat által kidolgozott módszer - a folyamatos, jelenléten alapuló mentorálási tevékenység egyéni és családi szinten. A szakértők hangsúlyozzák, hogy az érintett települések közösségeinek „jól-létére” is pozitív hatást gyakorolnak a felzárkózással kapcsolatos jó gyakorlatok, programok, mivel egyrészt infrastrukturálisan modernizálják a kistelepüléseket, másrészt növelik azok „képesség/ népesség" megtartó képességét.

A szemle következő cikkében Czibere Ibolya - egy, a társadalmi fejlesztésekben is megjelenő speciális közösségre - a roma nők csoportjára fókuszál. Tanulmányában a roma nők társadalmi szerepvállalását befolyásoló tényezőket járja körül. Czibere Ibolya szociológus szerint a roma nők helyzetét az interszekcionalitás elméleti megközelítésével lehet a legjobban leírni, ami esetükben az etnikai, nemi, társadalmi helyzetükből származó halmozott diszkriminációt jelenti - olyan területeken, mint az oktatás, egészségügy, szociális szolgáltatások, munkaerőpiac stb. A szakértő alaposan azonosítja és körbejárja azon egyenlőtlenségi viszonyokat, melyek leginkább befolyásolják és korlátozzák a roma nőket a társadalomba történő integrációjuk során.

Ezt követően Balcsók István összefoglalóját olvashatjuk a felzárkózáspolitika napjainkra jellemző kereteiről, a területi tudományok nézőpontjából. Tanulmányában három jelzőszámot ismertet, melyek fontos mutatók a területi különbségeket tekintve - szegregációs mutató, jövedelmi helyzetkép, lakhatási helyzetkép. A szakértő figyelemfelkeltő térképeinek köszönhetően az olvasó átfogó képet kap az egyenlőtlenségek területi leképeződéséről, amelyek egyben jól szemléltetik azokat a periférikus területeket is, amelyekkel a felzárkózáspolitikának foglalkoznia kell.

Hajnáczky Tamás cikkében a Kádár-korszakban végbemenő telepfelszámolással kapcsolatos történeti kutatások kerülnek bemutatásra. Összefoglalójában az 1960-as évektől kezdődően 1984-ig mutatja be a nyomortelepek átalakulását, azok közösségromboló és devianciákat felerősítő hatását. Jóllehet, a Kádár-korszakra jellemző sajátosságok nem minden esetben érvényesek napjainkra is, mégis a cikk újító jellegét az adja, hogy az adatokat egységes logikai rendszerben olvashatjuk, és következtethetünk a jelenlegi helyzet előzményeire.

Ongjerth Richárd cikkében a területi és településtervező szemszögéből ismerheti meg az olvasó a „vadtelep” kifejezéssel kapcsolatos gondolatokat. A szakember arra kérdez rá, hogy mennyire egységesek a leszakadó települések, a szegregált közösségek, illetve, hogy mit tekint a szociológia, szociálpolitika, településtervezés hátrányos helyzetű, emberi életre alig vagy egyáltalán nem alkalmas településrésznek, lakóhelynek. 


\section{RECENZIÓ}

A szemlében a tudományos tartalmak mellett olyan szakemberek életútját és munkásságát is megismerhetik az olvasók, akik fontosnak tartják a felzárkózás kérdését. Kiss Dávid, a Magyar Máltai Szeretetszolgálat szociális munkása kiemeli, hogy a folyamatos jelenlét a legfontosabb komponense a cigánytelepeken történő munkának. Baks polgármesterétől, Búza Zsolttól az „elődprojektben” megvalósult pályázat pozitív tapasztalatairól, a felmerülő nehézségekről, a többségi társadalom hozzáállásáról, a megvalósított szociális bérlakás programról és a sikeres felzárkózási program ismérveiről tudhat meg többet az olvasó. Kóti Tibor a Szociális és Gyermekvédelmi Főigazgatóság kiemelt projektjében dolgozó gyakornok szakmai életútján keresztül meséli el, hogy eddig milyen tudományos eredményeket tudott „felhalmozni”, amelyeket a későbbiekben a gyakorlatban is szeretne kamatoztatni e tevékenység során.

A szemle zárócikkében Dávid Orsolya és Jónás Etelka az Aronson-féle mozaik módszert mutatják be. A módszer ereje abban rejlik, hogy a csoportmunka eszközeivel hozzásegíti az eltérő etnikai hátterű diákokat a sikeresebb tanulmányi eredmények eléréséhez, és csökkenti a kirekesztés veszélyét.

A MaHolnap szemle stílusa szinergiában van a folyóirat témájával és céljával. A lap - klasszikus hálózatteremtő eszközként - segíthet abban, hogy összefogja a felzárkózással kapcsolatos jó példákat, bátorítsa, támogassa és tovább adja az egybegyűjtött eredményeket. Mindemellett disszeminációs csatornaként is fontos szerepet tölthet be a fenntarthatóság támogatásában. A szemle legfőbb értéke, hogy felhívja a figyelmet a téma jelentőségére, számos eddig elhanyagolt dimenziójára, és ezzel - remélhetőleg - tovább ösztönzi a hazai vizsgálatokat, a jó gyakorlatok terjedését, a szegregált élethelyezetek csökkentéséről szóló szakmai kommunikáció és cselekvés fenntartását.

Összességében céltudatosan megírt és szerkesztett szemlét kap kezébe a téma iránt érdeklődő, melynek olvasását jó szívvel ajánlom mindenkinek. 